\title{
Monogenoidea parasites of Oreochromis niloticus submitted to ractopamine supplemented diet from cultivated system
}

\author{
[Monogenoidea parasitos de Oreochromis niloticus provenientes de sistema de cultivo \\ submetidos a uma dieta suplementada com ractopamina] \\ M.C.N. Justo ${ }^{1}$. L.G. A. Nascimento ${ }^{1}$. Y.C. Meneses ${ }^{1}$. T. Trombeta ${ }^{2}$. S.C. Cohen ${ }^{1 *}$ \\ ${ }^{1}$ Laboratório de Helmintos Parasitos de Peixes - Instituto Oswaldo Cruz - Rio de Janeiro, RJ \\ ${ }^{2}$ Universidade Federal do Oeste do Pará - Santarém, PA
}

\begin{abstract}
Oreochromis niloticus (Linnaeus) (Perciformes: Cichlidae), commonly named "tilapia", is the second most cultivated species in the world. Among the diseases that affect tilapia are parasitic diseases caused by parasites of the class Monogenoidea. The aim of the present study was to analyze parasitism rates among specimens of $O$. niloticus in farming systems, after dietary supplementation with ractopamine, a growth promoter that is used for fattening fish. The action of this substance on the quantitative parameters of infestation by Monogenoidea was evaluated. Samples of $O$. niloticus were obtained from a fish farm in Brasília, Federal District, Brazil. Their gills were removed and fixed. Four species of monogenoideans were collected: Cichlidogyrus halli, C. sclerosus, C. thurstonae and Scutogyrus longicornis. The results from this study indicate that the monogenoidean parasites of tilapias examined here presented different behaviors in relation to the ractopamine concentrations that were added to the food. The parasitological indexes did not present significant reductions through using ractopamine, thus leading to the conclusion that administration of ractopamine is not efficient as a method for controlling infestations of monogenoidean parasites.
\end{abstract}

Keywords: Monogenoidea, Oreochromis niloticus, ractopamine, cultivated systems

\section{RESUMO}

Oreochromis niloticus (Linnaeus) (Perciformes: Cichlidae), tilápia, é a segunda espécie mais cultivada no mundo. Entre outras doenças que afetam a tilápia, estão as doenças provocadas por parasitos da classe Monogenoidea. O presente estudo teve como objetivo analisar os índices de parasitismo em espécies de $\mathrm{O}$. niloticus provenientes de sistemas de cultivo, submetidos a uma dieta com suplementação de ractopamina, usada como promotor de crescimento no estágio de engorda dos peixes, para avaliar as ações dessa substância nos parâmetros quantitativos da infestação por Monogenoidea. Exemplares de O. niloticus obtidos na piscicultura "Agropecuária do Buriti Perdido", em Brasília, Distrito Federal, Brasil, foram examinados; as brânquias foram removidas e fixadas. Quatro espécies foram coletadas: Cichlidogyrus halli, C. sclerosus, C. thurstonae e Scutogyrus longicornis. Os resultados obtidos no presente estudo indicaram que as espécies de Monogenoidea parasitos de tilápia examinadas apresentam diferentes comportamentos relacionados à concentração de ractopamina adicionada ao alimento. Os índices parasitológicos não apresentaram redução significativa pelo uso da ractopamina, levando à conclusão de que a ractopamina não é eficiente como método de controle parasitário em infestações por Monogenoidea.

Palavra-chave: Monogenoidea, Oreochromis niloticus, ractopamina, sistema de cultivo

Recebido em 6 de setembro de 2019

Aceito em 5 de março de 2020

*Autor para correspondência (corresponding author)

E-mail: scohen@ioc.fiocruz.br 


\section{INTRODUCTION}

Oreochromis niloticus (Linnaeus, 1758) (Perciformes: Cichlidae), commonly named "tilapia", is a member of the family Cichlidae and is native to Africa and the southwestern Middle East. Since the 1930s, tilapias have been intentionally dispersed worldwide (Canonico et al., 2005) such that they are now present on all continents (FAO, 2014). The hardiness of this species, its ease of adaptation and its omnivorous feeding habits, together with the accelerated growth and easily obtained larvae in intensive rearing are important characteristics that have favored the development of tilapia farming (Coward and Bromage, 2000).

Oreochromis niloticus is the second most frequently farmed species in the world, following carps (FAO, 2014), and is the first in Brazil (Portal Brasil, 2017). As one of the main producers of tilapias, Brazil has a very different market orientation compared to its Latin American counterparts, since $99 \%$ of its national production is consumed domestically (FAO, 2014).

Tilapias are used for biological control of aquatic weeds and insects, as baitfish in capture fisheries, for aquaria and as a food fish. They have most recently been promoted as an important source of protein that could provide food security for developing countries without the environmental problems associated with terrestrial agriculture (Canonico et al., 2005). On the other hand, it has been documented that they exert negative impacts on native biodiversity, given that these cichlids compete with native fish species for resources and habitat use. They sometimes consume the eggs, larvae and small individuals of other fish species; and have frequently co-introduced their parasites, some of which have switched host to indigenous fish species (García-Vásquez et al., 2017).

According to Vicente et al. (2014), tilapia production is growing year-by-year in Brazil. Consequently, concern about proper management and prophylaxis against various infectious agents is increasing. Over the last few decades, the parasites of introduced fish species have received attention because of their economic implications, especially in situations of intensive fish-farming (Martins et al., 2010). A great number of parasite species can cause mortality in fish farms and proper treatment can be a difficult and expensive process for producers to implement (Pavanelli et al., 2008).

The losses caused by parasites can be seen through reductions in assimilation and growth rates, along with diminished final value of the product (Eiras, 1994). Among the diseases that affect tilapia are parasitic diseases caused by parasites of the class Monogenoidea, that have been widely reported parasitizing the gills and body surface of $O$. niloticus in Brazil. Dactylogyridae of the genera Cichlidogyrus Paperna, 1960, Onchobdella Paperna, 1968, and Scutogyrus Pariselle \& Euzet, 1955; and Gyrodactylidae of the genus Gyrodactylus Normdmann, 1832, are the main species that inhabit these farmed fish (Ranzani-Paiva et al., 2005; Ghiraldelli et al., 2006; Graça and Machado, 2007; Lizama et al., 2007; Marengoni et al., 2009; Jeronimo et al., 2011; Pantoja et al., 2012; Bittencourt et al., 2014; Zago et al., 2014).

In 1964, in a study on the relationship between carps and protozoan and monogenoidean populations, Paperna \& Kohn observed that fish that were in a better nutritional condition presented lower infestation by monogenoideans (Paperna \& Kohn, 1964). Nutritional factors support physiological processes, stimulate host immunity and increase the presence of defense cells (Rotta, 2003; Fujimoto et al., 2010; BillerTakahashi, 2014). According to Fujimoto et al. (2010), vitamins and minerals are important in the physiological processes of fish species, through minimizing the effects of stressor agents.

Despite numerous studies within aquiculture, knowledge relating to nutrition in fish is scarce, in comparison with the amount of knowledge available on other species of zootechnical importance. Nonetheless, technology is widely applied in the stages of formulation and manipulation of nutritionally efficient diet (Pezzato et al., 2004). One of these examples is the use of food additives such as ractopamine (Mundim et al., 2016), which is known to improve food efficiency through reducing body fat content and increasing muscle growth in animals (Wendelaar Bonga, 1997).

However, supplementation with ractopamine may have a negative effect on animal welfare, such that typical stress alterations are generated, that may 
reflect negatively in the quality of the final product (Marchant-Forde et al., 2003). The stress within fish-farming may originate from various sources, such as fish handling, high stocking density, transportation, biological interactions, water quality and food management, including the use of nutritional additives (Mundim et al., 2016) and is known that is one of the triggers of monogenoidean infestations in farming systems.

The aim of the present study was to analyze parasitism rates among specimens of $O$. niloticus in farming systems, after dietary supplementation with ractopamine, a growth promoter that is used for fattening fish. The action of this substance on the quantitative parameters of infestation by Monogenoidea was evaluated.

\section{MATERIAL AND METHODS}

Samples of $O$. niloticus were obtained from the farm "Agropecuária do Buriti Perdido", in Brasília, Federal District, Brazil. For this study on the effects of dietary supplementation with ractopamine, only male fish were selected, considering that they present better growth performance than females. Forty-one specimens of $O$. niloticus that were submitted to the treatment were analyzed.

The experiment was conducted in the "Centro de Tecnologia em Piscicultura da Secretaria de Agricultura do Distrito Federal," in Brasília, Brazil. The study was done in a closed system of recirculation, with mechanical and biological filters with a volume of $14.8 \mathrm{~m}^{3}$ and maximum filtration capacity of $20 \mathrm{~L} / \mathrm{min}$. A total of 112 specimens of $O$. niloticus were distributed randomly in 16 tanks of 500L that were installed in a closed and covered environment. Their initial weight was $519.37 \pm 114.3 \mathrm{~g}$ and they were individually identified using PIT-tags.

There was a pre-experimental period of 20 days for the fish to become acclimatized to the tanks. Over the first 10 days of this period, they were fed twice a day with commercial pellets (32\% crude protein, $5 \%$ lipids and $3,000 \mathrm{kcal} / \mathrm{kg}$ of energy), i.e. the same food that they had been consuming under fish-farming conditions. Over the second 10 days of this period, they were fed with baseline pellets of the control diet.
The system was oxygenated through silicone hoses of $4 \mathrm{~mm}$ in diameter, with a porous stone at one end, connected to a PVC tube fed with a $0.75 \mathrm{HP}$ compressor. The water temperature was controlled through $16500 \mathrm{~W}$ thermostats that were installed individually inside each tank. The fishes were kept under natural photoperiod conditions (12h of light and $12 \mathrm{~h}$ of darkness).

The experimental design was completely randomized, with four treatments with ractopamine incorporated into the food at different concentrations: 0ppm of ractopamine, $10 \mathrm{ppm}$ of ractopamine, $20 \mathrm{ppm}$ of ractopamine and 40ppm of ractopamine. Thus, among the 16 tanks, there were four tanks per treatment (i.e. four replications). At the end of the experimental period, fish specimens were chosen randomly and anesthetized with clove oil at a dosage of $50 \mathrm{mg} \mathrm{L}$ 1 (Inoue et al., 2003).

The gills were removed and placed in vials containing 1:4,000 formalin solution and shaken vigorously and the formalin solution of each vial was then increased to about 5\%. The samples were then sent to the "Laboratório de Helmintos Parasitos de Peixes - LHPP, Instituto Oswaldo Cruz", in Rio de Janeiro, to be examined. In the laboratory, parasites were collected with the aid of a stereoscopic microscope and were stored in the same fixative. Some specimens were mounted unstained in Hoyer's mounting medium in order to study the sclerotized parts. The remainder were stained with Gomori's trichrome, cleared in beechwood creosote and mounted on slides in Canada balsam.

All the specimens were observed under a Zeiss Axioskop bright-field microscope, equipped with a millimeter-grid eyepiece and with differential interference contrast (DIC) optics, and were photographed using a Sony MPEGEX digital camera that was coupled to this microscope. All measurements were expressed in micrometers, taking the scheme shown in Figure 1, and are presented here as the mean \pm standard deviation. The mean is followed by the range and the number of specimens measured (when greater than two) in parentheses. Representative specimens were deposited in the Helminthological Collection of the Instituto Oswaldo Cruz (CHIOC) in Brazil.

The data were compared using one-way analysis of variance (ANOVA) and treatment means were 
compared using the Tukey's test. The $p$ values less than or equal to 0.05 were considered statistically significant. The prevalence $(\mathrm{P})$, mean abundance (MA) and mean intensity (MI) of the parasites were calculated assuming binominal distribution, using the Quantitative Parasitology 3.0 statistical software (Bush et al. 1997; Rózsa et al. 2000).
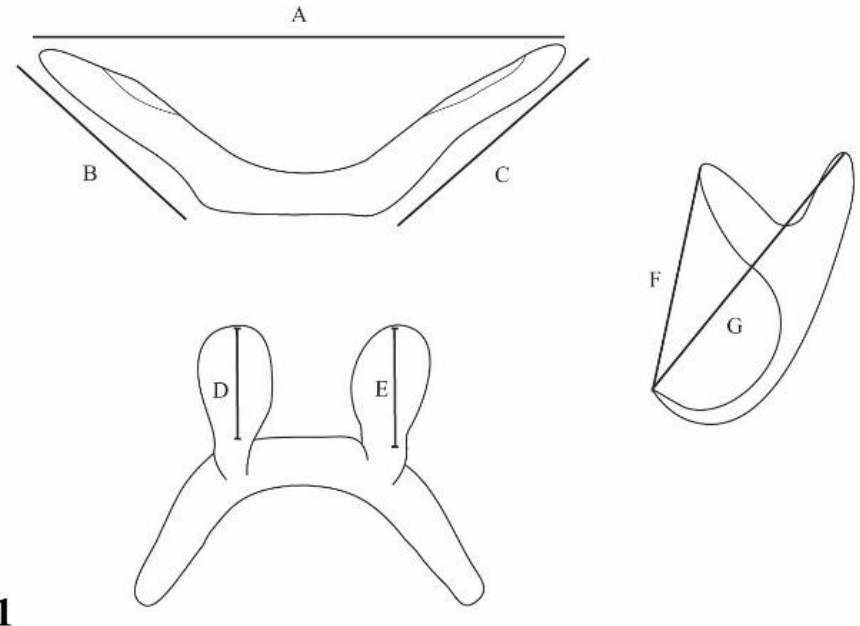

Figure 1. Measurement protocol for some haptoral structures.

\section{RESULTS AND DISCUSSION}

Forty-one specimens of $O$. niloticus of total weight $\quad 478-727 \mathrm{~g} \quad(582.05 \pm 74.83 \mathrm{~g}) \quad$ were examined for the presence of monogenoideans and $36(88 \%)$ were found to be parasitized by at least one species of Monogenoidea. Four species were collected: Cichlidogyrus halli Price \& Kirk, 1967 (Figure 2a-c), Cichlidogyrus sclerosus Paperna \& Thurston, 1969 (Figure 2d-f), Cichlidogyrus thurstonae Ergens, 1981 (Figure 2g-i), and Scutogyrus longicornis (Paperna \& Thurston, 1969) (Figure 2j-1).

The morphometric analysis on the four species collected in the gills of these $O$. niloticus specimens from the commercial fish-farm "Agropecuária do Buriti Perdido", Brasília (Table 1) showed that they were compatible with species that had previously been described and were known to be parasites of tilapias.

Cichlidogyrus halli presented the highest prevalence rate $(63.4 \%)$ (MI: 9.19; MA: 5.83; IR: $1-43$, with a total of 239 specimens), followed by C. sclerosus (58.5\%) (MI: 18.08; MA: 10.59; IR: 1-137, with a total of 434 specimens), $S$. longicornis (22\%) (MI: 2.44; MA: 0.54; IR: 1-5, with a total of 22 specimens) and $C$. thurstonae (14.06\%) (MI: 2; MA: 0.29; IR: 1-4, with a total of 12 specimens).

After administration of the ractopaminesupplemented food, it was observed that the prevalence of three of the monogenean species increased. The exception was $C$. thurstonae, which was absent in the control and presented prevalence of $10 \%$ at the concentration of $10 \mathrm{ppm}$ and $40 \%$ at $20 \mathrm{ppm}$, but only $14.3 \%$ at $40 \mathrm{ppm}$, i.e. a decrease.

According to Marchant-Forde et al. (2003), supplementation with ractopamine may have a negative effect on animal welfare, thus generating typical alterations of stress. In this light, increased stress in fish may lead to higher parasitological indexes. There were no statistically significant differences $(\mathrm{P}>0.05)$ in prevalence between the control group and the experimental groups after exposure to the monogenean parasites or to the different concentrations of ractopamine that were added to the food. Similarly, for all other parasitological index parameters tested between species and treatment groups, no statistically significant differences were observed $(\mathrm{P}>0.05)$. 


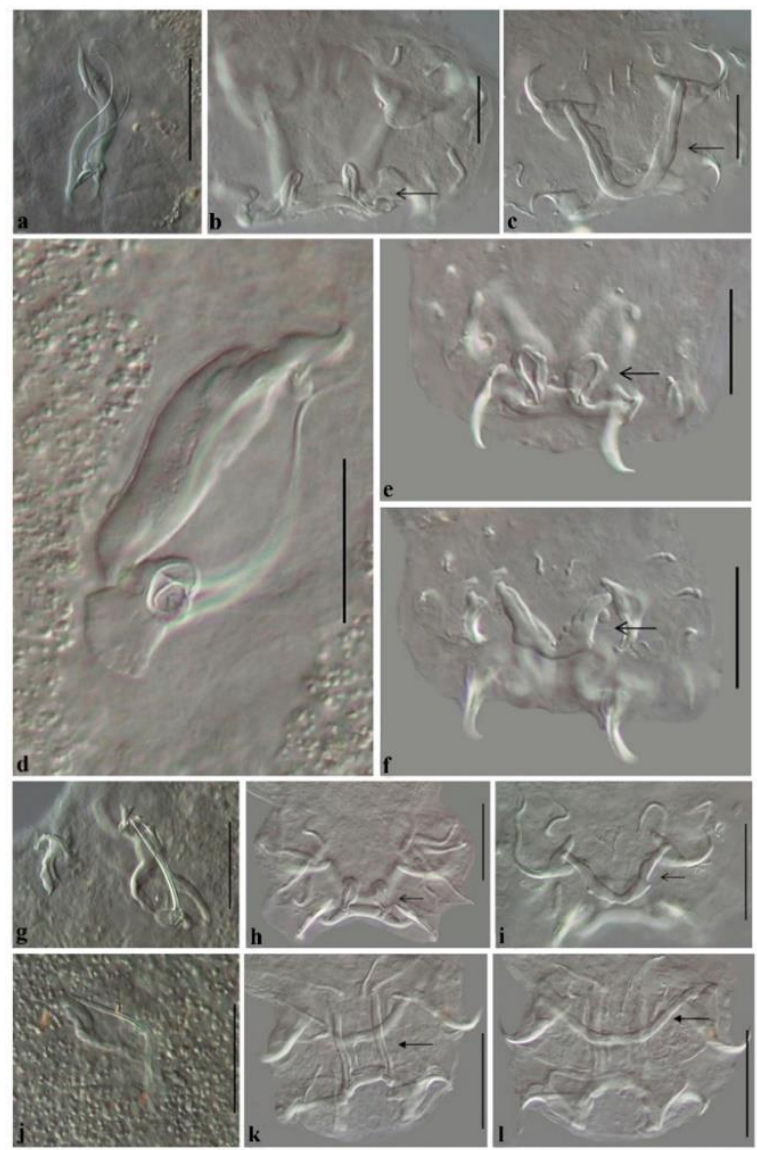

Figure 2. Photomicrographies of sclerotized parts of Monogenoidea parasites of Oreochromis niloticus obtained from the farm "Agropecuária do Buriti Perdido", in Brasília, Federal District, Brazil. a-c Cichlidogyrus halli (Price \& Kirk, 1967). a. Copulatory complex. b. Haptor showing dorsal bar with projections (arrow). c. Haptor showing ventral bar (arrow). d-f Cichlidogyrus sclerosus Paperna \& Thurston, 1969. d. Copulatory complex. e. Haptor showing dorsal bar with projections (arrow). f. Haptor showing ventral bar (arrow). g-i Cichlidogyrus thurstonae Ergens, 1981. g. Copulatory complex. h. Haptor showing dorsal bar with projections (arrow). i. Haptor showing ventral bar (arrow). j-1 Scutogyrus longicornis (Paperna \& Thurston, 1969). j. Copulatory complex. k. Haptor showing dorsal bar with projections (arrow). 1. Haptor showing ventral bar (arrow). Scale-bars: Figure a, d, g, j: 30 $\mu$ m; Figure b-c, e-f, h-i, k-l: $50 \mu \mathrm{m}$.

Cichlidogyrus is the most species-rich genus of Monogenoidea, and its species almost exclusively parasitizing Cichlidae (a few representatives of Cichlidogyrus also occur in Cyprinodontidae and Nandidae) (Rahmouni et al., 2017). In South America, this genus was first reported by Thatcher (1991) parasitizing O. mossambicus (Peters, 1852) (=Tilapia mossambica) in Colombia. Later, many reports of this genus parasitizing $O$. niloticus in different states of Brazil have been published. Cichlidogyrus sp. was reported parasitizing farmed fishes in Paraná by Graça and Machado (2007); in Santa Catarina by Azevedo et al. (2006), Ghiraldelli et al. (2006) and Martins et al. (2010); and in São Paulo by Ranzani-Paiva et al. (2005), Lizama et al. (2007) and Zago et al. (2014). Cichlidogyrus halli and Cichlidogyrus thurstonae were recorded in Santa Catarina by Jeronimo et al. (2011) and in São Paulo by Zago et al. (2014). Cichlidogyrus sclerosus was reported in Santa Catarina by Ghiraldelli et al. (2006) and Jeronimo et al. (2011); in São Paulo by Lizama et al. (2007); in Paraná by Graça and Machado (2007); in Santa Catarina by Azevedo et al. (2006) and Martins et al. (2010); and in Rio de Janeiro by Silva et al. (2015). 
Table 1. Main measurements of species of Monogenoidea found parasitizing Oreochromis niloticus coming from the farming “Agropecuária do Buriti Perdido", in Brasília, Federal District, Brazil

\begin{tabular}{|c|c|c|c|c|}
\hline & $\begin{array}{l}\text { Cichlidogyrus } \\
\text { sclerosus }\end{array}$ & $\begin{array}{c}\text { Cichlidogyrus } \\
\text { thurstonae }\end{array}$ & $\begin{array}{l}\text { Scutogyrus } \\
\text { longicornis }\end{array}$ & $\begin{array}{l}\text { Cichlidogyrus } \\
\text { halli }\end{array}$ \\
\hline Body length & $659(400-850)$ & $387(300-470)$ & $604(510-720)$ & $759(700-860)$ \\
\hline Body width & $238(200-280)$ & $110(100-220)$ & $149(100-200)$ & $266(200-330)$ \\
\hline Pharynx length & $61(55-66)$ & & & \\
\hline Pharynx width & $59(47-74)$ & & & \\
\hline Haptor length & $122(105-155)$ & $115(91-150)$ & & \\
\hline Haptor width & $92(70-110)$ & $77(53-110)$ & $130(108-145)$ & \\
\hline \multicolumn{5}{|l|}{ Ventral bar } \\
\hline A & $41(40-45)$ & $42(25-56)$ & $70(45-90)$ & $95(75-120)$ \\
\hline B & $41(37-45)$ & $36(25-43)$ & $41(40-50)$ & 77(57-87) \\
\hline $\mathrm{C}$ & $41(35-44)$ & $35(30-43)$ & $35(30-50)$ & $77(57-87)$ \\
\hline \multicolumn{5}{|l|}{ Dorsal bar } \\
\hline $\mathrm{D}$ & $24(17-31)$ & $19(13-23)$ & $51(40-75)$ & $21(15-32)$ \\
\hline $\mathrm{E}$ & $25(18-30)$ & $19(15-22)$ & $49(40-75)$ & $21(15-25)$ \\
\hline $\mathrm{F}$ & $53(35-63)$ & $47(35-55)$ & $48(32-82$ & $84(75-100)$ \\
\hline \multicolumn{5}{|l|}{ Ventral anchor } \\
\hline G & $30(26-36)$ & $29(25-34)$ & $31(17-40)$ & $48(37-55)$ \\
\hline $\mathrm{H}$ & $33(27-36)$ & $34(31-40)$ & $35(27-60)$ & $46(42-50)$ \\
\hline \multicolumn{5}{|l|}{ Dorsal anchor } \\
\hline G & $30(20-33)$ & $26(15-32)$ & $27(15-35)$ & $40(32-50)$ \\
\hline $\mathrm{H}$ & $32(28-40)$ & $29(20-34)$ & $32(22-50)$ & $41(35-47)$ \\
\hline $\begin{array}{l}\text { Male copulatory } \\
\text { organ (I) }\end{array}$ & $75(63-86)$ & $47(37-60)$ & & $81(67-93)$ \\
\hline Accessory piece $(\mathrm{J})$ & $61(50-67)$ & $51(29-71)$ & & $64(59-75)$ \\
\hline Deposited specimens & CHIOC 39269 a-e & $\begin{array}{l}\text { CHIOC } 39270, \\
39271 \text { a-c }\end{array}$ & $\begin{array}{l}\text { CHIOC 39272, } \\
\text { 39273a-c, } 39274\end{array}$ & $\begin{array}{c}\text { CHIOC 39265a- } \\
\text { b,39266, 39267, 39268 }\end{array}$ \\
\hline
\end{tabular}

Letters in parenthesis refers to measurements given in Figure 1.

Scutogyrus longicornis was originally described as belonging to the genus Cichlidogyrus, and was observed parasitizing tilapias in Uganda, Africa, by Paperna and Thurston in 1969. Pariselle and Euzet (1995) erected Scutogyrus and transferred the species to this genus. Scutogyrus longicornis was recorded in Santa Catarina by Jeronimo et al. (2011); in Paraná by Graça and Machado (2007) and in São Paulo by Zago et al. (2014). Cichlidogyrus tilapiae, which was not found in $O$. niloticus in the present study, had been previously reported in Amapá by Pantoja et al. (2012) and Bittencourt et al. (2014); and in Rio de Janeiro by Silva et al. (2015).

Lizama et al. (2007) examined specimens of $O$. niloticus from fish farms in Assis, São Paulo, and found $C$. sclerosus and another four different unidentified Cichlidogyrus species. These authors reported that the highest prevalence was of Cichlidogyrus sp. 1 and C. sclerosus $(43.8 \%$ and $40.4 \%$, respectively), followed by the other species, with similar mean intensity and mean abundance values for all the five species found. The quantitative parameter values observed for $C$. sclerosus in the present study were higher than those observed by Lizama et al. (2007) for this species (40.4\%; MI: 6.4; MA: 2.6; and IR: 1-24 in their study, versus 58.5\%; MI: 18.08; MA: 10.59; and IR: $1-137$ in the present study).

Silva et al. (2015) studied specimens of $O$. niloticus from an urban lake in the municipality of Itaperuna, Rio de Janeiro, which were obtained at two different collection times. In February 2015, the prevalence was $C$. tilapiae $100 \%$ and $C$. sclerosus $0 \%$ (zero). In the second collection, in May 2016, the prevalence was C. tilapiae $44.44 \%$ and C. sclerosus $88.88 \%$.

Zago et al. (2014) examined farmed fish at three different growth phases, according to their weight, which were classified as initial, intermediate and final: $\leq 150 \mathrm{~g} ; 151-400 \mathrm{~g}$; and 401-800g, respectively. The prevalence of Cichlidogyrus halli found in the initial phase $(61.9 \%)$ by these authors was similar to what was seen in the present study $(63.4 \%)$; while the prevalence was higher in the intermediate and final phases (100\% and $90.5 \%$ ). Regarding mean 
intensity, the value of the present study (9.19) was higher than the values found by Zago et al. (2014) (5.3, 4.5 and 7.2 in the initial, intermediate and final phases, respectively). Regarding mean abundance, which was 3.3, 4.5 and 8.0 in the different phases of the hosts examined by Zago et al. (2014), their values are similar than those of the present study. All the parameters found by Zago et al. (2014) for Cichlidogyrus thurstonae were higher than those in the present study, regarding prevalence, mean intensity and mean abundance.

The parasitological parameters for Scutogyrus longicornis observed in the present study (22\%) were different from those in the study by Zago et al. (2014), that found higher prevalence indexes $(42.9 \%, 85.7 \%$ and $76.2 \%)$. On the other hand, their intensity values were $0.3,1.6$ and 1.7 in the different phases of growth, i.e. lower than the value found in the present study (2.44). The mean abundances of $S$. longicornis found by Zago et al. (2014) were $0.1,1.4$ and 1.3 , i.e. values that were higher than what was observed in the present study. For all the parasitological index parameters tested between species and treatment groups in the present study, no statistically significant differences were observed $(\mathrm{P}>0.05)$.

Monogenoideans are parasites with direct life cycle and they are resistant to elimination when translocated (Pérez-Ponce de León et al., 2000). Thus, species of the genus Cichlidogyrus that were translocated via $O$. niloticus were found to have colonized species of endemic cichlids in Mexico (Jiménez-García et al., 2001) and Panama (Roche et al., 2010) and in several records in Brazil (cited above) due to the relative parasite specificity (Bittencourt et al., 2014).

According to Kubitza and Kubitza (2000), the susceptibility of tilapias to parasitosis and other illnesses depends on various factors, including the parasite species or lineages, water quality and organic load in farm production units, nutritional condition of the fish and, especially, water temperature (Marengoni et al., 2009). Records from monogenoideans that were found in farmed tilapias in Brazil, including in the present study, have shown that these fish are parasitized by monogenoidean fauna that are similar to those of the original locality. It is known that $O$. niloticus in the Nile River hosts the following species: Cichlidogyrus tilapiae, C. aegypticus, C. cirratus, $C$. halli, $C$. thurstonae, $C$. arthracanthus, Scutogyrus longicornis, Gyrodactylus cichlidarum and Enterogyrus cichlidarum, demonstrating that tilapias co-introduced some of their monogenoidean parasites following their invasions.

The results obtained from the present study indicate that monogenoidean parasites of tilapias from the farm "Agropecuária do Buriti Perdido" presented different behaviors relating to the ractopamine concentrations that were added to the food. Cichlidogyrus halli presented lower prevalence at the concentration of 10ppm (40\%), compared with the control $(80 \%)$, but lower mean intensity and abundance were observed at concentrations of 40ppm (4.3 for both indexes) and 10ppm (6.0 and 2.4, respectively). Cichlidogyrus sclerosus showed lower parameters at the concentration of 10ppm. Cichlidogyrus thurstonae was not observed in the control samples but was found parasitizing tilapias fed with different concentrations of ractopamine. Together with $S$. longicornis, $C$. thurstonae presented lower indexes, compared with the other species.

According to Trombeta (2016), use of ractopamine proved to be efficient for decreasing the fat content in tilapia fillets. However, this did not present significant results with regard to improvement of zootechnical performance. Regarding the control of parasites, ractopamine did not prove to be efficient as a method for parasitic control regarding monogenoidean infestations. Considering the increasing levels of tilapia farming in Brazil, further studies combining different substances to define their efficacy for controlling monogenoidean species in farmed fish are necessary. 


\section{REFERENCES}

AZEVEDO, T.M.O.; MARTINS, M.L.; BOZZO, F.R.; MORAES, F.R. Haematological and gill responses in parasitized tilapia from valley of Tijucas River, SC, Brazil. Sci. Agric., v.63, p.115120, 2006.

BILLER-TAKAHASHI, J.D. Imunoestimulantes e imunidade de organismos aquáticos. In: MADI, R.R.; CAMPOS, C.M.; LIZAMA, M.A.P.; TAKEMOTO, R.M. (Orgs.). Patologia $e$ sanidade em ambientes aquáticos. Maringa: Massoni, 2014. 342p.

BITTENCOURT, L.S.; PINHEIRO, D.A.; CÁRDENAS, M.Q. et al. Parasites of native Cichlidae populations and invasive Oreochromis niloticus (Linnaeus, 1758) in tributary of Amazonas River (Brazil). Braz. J. Vet. Parasitol., v.23, p.44-54, 2014.

BUSH, A.O.; LAFFERTY, K.D.; LOTZ, J.M.; SHOSTAK, A.W. Parasitology meets ecology on its own terms: Margolis et al. Revisited. J. Parasitol., v.83, p.575-583, 1997.

COWARD, K.; BROMAGE, N.R. Reproductive physiology of female tilapia brood stock. Rev. Fish. Biol., v.10, p.1-25, 2000.

EIRAS, E.C.; TAKEMOTO, R.M.; PAVANELLI, G.C. Métodos de estudos e técnicas laboratoriais em parasitos de peixes. 2.ed. Maringá: Eduem, 2000. 199p.

FAO, 2014. Cultured aquatic species information programme, Oreochromis niliticus (Linnaeus, 1758). In on Food and Agriculture Organization of the United Nation, Rome, Italy. http://www.fao.org/fishery/culturedspecies/Oreo chromis_niloticus/en

FUJIMOTO, R.Y.; CASTRO, M.P.; MARTINS, M.L. et al. Effects of chromiun supplementation on the infrapopulations of Anacanthorus penilabiatus (Monogenoidea) and Piscinoodinium pillulare (Dinoflagellida) parasites of Piaractus mesopotamicus (Characidae). Braz. Arch. Biol. Technol., v.53, p.827-833, 2010.
GARCIA-VASQUEZ A.; RAZO-MENDIVIL, U.; RUBIO-GODOY, M. Triple trouble? Invasive poeciliid fishes carry the introduced tilapia pathogen Gyrodactylus cichlidarum in the Mexican highlands. Vet. Parasitol., v.235, p.3740, 2017.

GHIRALDELLI, L.; MARTINS, M.L.; JERÔNIMO, G.T. et al. Ectoparasites communities from Oreochromis niloticus cultivated in the State of Santa Catarina, Brazil. $J$. Fish. Aquat. Sci., v.1, p.181-90, 2006.

GRAÇA, R.J.; MACHADO, M.H. Ocorrência e aspectos ecológicos de metazoários parasitos de peixes do Lago do Parque do Ingá, Maringá, Estado do Paraná. Acta Sci. Biol. Sci., v.29, p.321326, 2007.

HUMASON, G.L. Animal tissue techniques. 4.ed. San Francisco: W.H. Freeman and Company, 1979. 661p.

INOUE, L.A.K.A.; SANTOS NETO, C.; MORAES, G. Clove oil as anaesthetic for juveniles of matrinxã Brycon cephalus (Gunther, 1869). Cienc. Rural, v.33, p.943-947, 2003.

JERONIMO, G.T.; SPECK, G.M.; CECHINEL, M.M. et al. Seasonal variation on the ectoparasitic communities of Nile tilapia cultured in three regions in south Brazil. Braz. J. Biol., v.71, p.365373, 2011.

JERONIMO, G.T.; SPECK, G.M.; MARTINS, M.L. First report of Enterogyrus cichlidarum Paperna, $1963 \quad$ (Monogenoidea: Ancyrocephalidae) on Nile tilapia Oreochromis niloticus cultured in Brazil. Neotrop. Helminthol., v.4, p.75-80, 2010.

KRITSKY, D.C.; LEIBY, P.D.; KAYTON, R.J. $A$ rapid stain technique for haptoral bars of Gyrodactylus species (Monogenea). J. Parasitol., v.69, p.862-865, 1978.

KUBITZA, L.M.; KUBITZA, F. Principais parasitoses e doenças em tilápia. Panorama Aquicul., v.10, p.39-53, 2000.

LEONARDO, J.M.L.O; PEREIRA, J.V.; KRAJEVIESKI, M.E. Ocorrência de ectoparasitas e estacionalidade em alevinos de tilápia do Nilo (Oreochromis niloticus) após a reversão sexual, na região noroeste do Paraná. Iniciação Cient. CESUMAR, v.8, p.185-191, 2006. 
LIZAMA, M.A.P.; TAKEMOTO, R.M.; RANZANI-PAIVA, M.J.T. et al. Relação parasito-hospedeiro em peixes de pisciculturas da região de Assis, Estado de São Paulo, Brasil. Oreochromis niloticus (Linnaeus, 1757). Acta Sci. Biol. Sci., v.29, p.223-231, 2007.

MARCHANT-FORDE，J.N.; LAY， D.C.J.R.; PAJOR, E.A. The effects of ractopamine on the behavior and physiology of finishing pigs. $J$. Anim. Sci., v.81, p.416-422, 2003.

MARENGONI, N.G.; SANTOS, R.S.; GONÇALVES JÚNIOR, A.C. et al. Monogenoidea (Dactylogyridae) em tilápias-donilo cultivadas sob diferentes densidades de estocagem em tanques-rede Arq. Bras. Med. Vet. Zootec., v.61, p.393-400, 2009.

MARTINS, M.L.; AZEVEDO, T.M.P.; GHIRALDELLI, L. et al. Can the parasitic fauna on Nile tilapias be affected by different production systems? Ann. Acad. Bras. Cien., v.82, p.493-500, 2010.

MILLS, S.E.; SPURLOCK. M.E.; SMITH, D.J. Beta-adrenergic receptor subtypes that mediate ractopamine stimulation of lipolysis. J. Anim. Sci., v.81, p.662-668, 2003.

MUNDIM, A.P.P.; BERNAL, F.E.M.; CARRAZZA, L.G. et al. Indicadores hematológicos e bioquímicos do estresse em Tilápias (Oreochromis niloticus), suplementadas com ractopamina. Arch. Vet. Sci., v.21, p.87-96, 2016.

OLIVEIRA, E.G.; SANTOS, F.J.S.; PEREIRA, A.M.L. et al. Produção de tilápia: Mercado, espécie, biologia e recria. Teresina: Embrapa, 2007. 12p. (Circular Técnica, n.45).

PANTOJA, W.M.F.; NEVES, R.L.; DIAS, M.R.D. et al. Protozoan and metazoan parasites of Nile tilapia Oreochromis niloticus cultured in Brazil. Rev. Med. Vet. Zootec., v.17, p.2812-2818, 2012.

PAPERNA, I.; KOHN, A. Studies on the hostparasite relations between carps and populations of protozoa and monogenetic trematodes in mixed infestations. Rev. Bras. Biol., v.24, p.269-276, 1964.
PARISELLE, A.; EUZET, L. Four new species of Cichlidogyrus (Monogenea: Ancyrocephalidae), gill parasites of Tilapia cabrae (Teleostei: Cichlidae), with discussion of relative length of haptoral sclerites. Folia Parasitol., v.50, p.195201, 2003.

PARISELLE, A.; EUZET. L. Gill parasites of the genus Cichlidogyrus Paperna, 1960 (Monogenea, Ancyrocephalidae) from Tilapia guineensis (Bleeker, 1862), with descriptions of six new species. Syst. Parasitol., v.30, p.187-198, 1995.

PEZZATO, L.E.; BARROS, M.M.; FRACALOSSI, D.M. et al. Nutrição de peixes. In: CYRINO, J.E.P.; URBINATI, E.C.; FRACALOSSI, D.M. (Eds.). Tópicos especiais em piscicultura de água doce tropical intensiva. São Paulo: Aquabil, 2004. p.75-172.

RANZANI-PAIVA, M.J.T.; FELIZARDO, N.N.; LUQUE, J.L. Parasitological and hematological analysis of Nile tilapia Oreochromis niloticus Linnaeus, 1757 from Guarapiranga reservoir, São Paulo State, Brazil. Acta Sci. Biol. Sci., v.27, p.231-237, 2005.

ROTTA, M.A Utilização do ácido ascórbico (vitamina $C$ ) pelos peixes. Corumbá: Embrapa Pantanal, 2003. 54p.

SILVA, C.M.; BATISTA, R.C.; THOMÉ, M.P.M. Prevalência de Cichlidogyrus spp. (Monogenea) em Oreocrhomis niloticus (Linnaeu, 1757) num lago urbano do Municipio de Itaperuna, Rio de janeiro, Brasil. Rev. Interdisc. Pensamento Cient., v.2, p.136-145, 2015.

THATCHER, V.E. Amazon fish parasites. Amazoniana, v.11, p.263-572, 1991.

VICENTE, I.S.T.; ELIAS, F.; FONSECAALVES, C.E. Perspectivas da produção de tilápia do Nilo (Oreochromis niloticus) no Brasil. Rev. Ciênc. Agrar., v.37, p.392-398, 2014.

WENDELA ARBONGA, S.E. The stress response in fish. Physiol. Rev., v.77, p.591-625, 1997.

ZAGO, A.C.; FRANCESCHINI, L.; GARCIA, F. Ectoparasites of Nile tilapia (Oreochromis niloticus) in cage farming in a hydroelectric reservoir in Brazil. Braz. J. Vet. Parasitol., v.23, p.171-178, 2014. 